\title{
Synthesis and Characterization of Transition Metal Complexes of Chlorpromazine
}

\author{
Yakubreddy Naini ${ }^{1}$, Tarab J. Ahmad ${ }^{1}$, Gilles K. Kouassi ${ }^{1}$, S. Ananda ${ }^{2}$, Netkal M. Made Gowda ${ }^{1, *}$ \\ ${ }^{1}$ Department of Chemistry, Western Illinois University, One University Circle, Macomb, 61455, USA \\ ${ }^{2}$ Department of Studies in Chemistry, University of Mysore, Manasagangothri, Mysore, 570 006, India
}

\begin{abstract}
The chlorpromazine (CP) complexes of the transition metal ions, $\mathrm{Zn}(\mathrm{II}), \mathrm{Cd}(\mathrm{II})$ and $\mathrm{Hg}(\mathrm{II})$, have been synthesized. The complexes have been characterized by their elemental analysis, molar conductivity, magnetic susceptibility, UV-Visible, IR and ${ }^{1} \mathrm{H}-\mathrm{NMR}$ data. The molecular formulations of the new mononuclear complexes have been found to be $\left[\mathrm{ZnBr}\left(\mathrm{C}_{17} \mathrm{H}_{19} \mathrm{ClN}_{2} \mathrm{~S} . \mathrm{HCl}\right)_{2}\right] \mathrm{Br},\left[\mathrm{CdBr}\left(\mathrm{C}_{17} \mathrm{H}_{19} \mathrm{ClN}_{2} \mathrm{~S} . \mathrm{HCl}\right)_{2}\right] \mathrm{Br} . \mathrm{H}_{2} \mathrm{O},\left[\mathrm{Cd}\left(\mathrm{C}_{17} \mathrm{H}_{19} \mathrm{ClN}_{2} \mathrm{~S} . \mathrm{HCl}\right)_{2}\right] \mathrm{I}_{2}$ and $\left[\mathrm{HgBr}\left(\left(\mathrm{C}_{17} \mathrm{H}_{19} \mathrm{C}\right.\right.\right.$ $\left.\left.1 \mathrm{~N}_{2} \mathrm{~S} . \mathrm{HBr}\right)_{2}\right] \mathrm{Br} .2 \mathrm{H}_{2} \mathrm{O}$, where the ligand chlorpromazine or $\mathrm{CP}=\mathrm{C}_{17} \mathrm{H}_{19} \mathrm{ClN}_{2} \mathrm{~S}$. The complexes, $\left[\mathrm{ZnBr}\left(\mathrm{C}_{17} \mathrm{H}_{19} \mathrm{ClN}_{2} \mathrm{~S} . \mathrm{HCl}\right)_{2}\right] \mathrm{Br}$, $\left[\mathrm{CdBr}\left(\mathrm{C}_{17} \mathrm{H}_{19} \mathrm{ClN}_{2} \mathrm{~S} . \mathrm{HCl}\right)_{2}\right] \mathrm{Br} . \mathrm{H}_{2} \mathrm{O}$, and $\left[\mathrm{HgBr}\left(\left(\mathrm{C}_{17} \mathrm{H}_{19} \mathrm{ClN}_{2} \mathrm{~S} . \mathrm{HBr}\right)_{2}\right] \mathrm{Br} .2 \mathrm{H}_{2} \mathrm{O}\right.$, behave in DMF solutions as 1:1 electrolytes while the other complex, $\left[\mathrm{Cd}\left(\mathrm{C}_{17} \mathrm{H}_{19} \mathrm{ClN}_{2} \mathrm{~S} . \mathrm{HCl}\right)_{2}\right] \mathrm{I}_{2}$, shows an ionic ratio of 1:2 in solution. Molecular structures have been proposed showing a square pyramidal environment around each metal center with an $\mathrm{sp}^{3} \mathrm{~d}$ hybridization for the five-coordinate complexes, $\left[\mathrm{ZnBr}\left(\mathrm{C}_{17} \mathrm{H}_{19} \mathrm{ClN}_{2} \mathrm{~S} . \mathrm{HCl}\right)_{2}\right] \mathrm{Br}$, [CdBr$\left.\left(\mathrm{C}_{17} \mathrm{H}_{19} \mathrm{ClN}_{2} \mathrm{~S} . \mathrm{HCl}\right)_{2}\right] \mathrm{Br} . \mathrm{H}_{2} \mathrm{O}$, and $\left[\mathrm{HgBr}\left(\left(\mathrm{C}_{17} \mathrm{H}_{19} \mathrm{Cl}\right.\right.\right.$ $\left.\left.\mathrm{N}_{2} \mathrm{~S} . \mathrm{HBr}\right)_{2}\right] \mathrm{Br} .2 \mathrm{H}_{2} \mathrm{O}$. In the four-coordinate $\left[\mathrm{Cd}\left(\mathrm{C}_{17} \mathrm{H}_{19} \mathrm{ClN}_{2} \mathrm{~S} . \mathrm{HCl}\right)_{2}\right] \mathrm{I}_{2}$ complex, the $\mathrm{Cd}(\mathrm{II})$ center with an sp ${ }^{3}$ hybridization has a tetrahedral environment around it.
\end{abstract}

Keywords Chlorpromazine, Metal Complexes, Synthesis, Characterization, Analysis

\section{Introduction}

The N-alkylamino phenothiazine derivatives (NPTZs) including chlorpromazine $(\mathrm{CP})$ are biologically active heterocyclic compounds. Structurally, CP is a phenothiazine substituted with chlorine and tert-alkylamine groups at 2 and 10 positions, respectively (Fig. 1). The NPTZ derivatives find extensive applications in the field of medicine as antipsychotic, anxiolytic, antiemetic and inodilationdrugs[13].

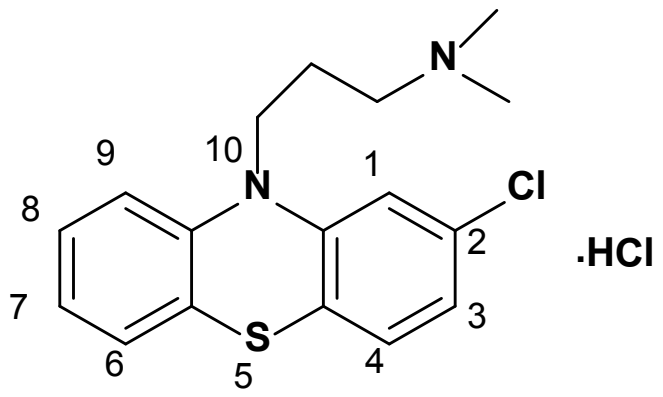

Figure 1. Molecular structure of chlorpromazine hydrochloride

Previously, some studies of transition metal-NPTZ complexes have been reported by several workers[4-16].

* Corresponding author:

GN-Made@wiu.edu (Netkal M. Made Gowda)

Published online at http://journal.sapub.org/chemistry

Copyright (C) 2012 Scientific \& Academic Publishing. All Rights Reserved
Keshavan and co-workers[4-7] have synthesized and characterized compounds of selected NPTZs with molybdenum(IV), tungsten(IV), ruthenium(II/III) and copper(II). Keshavan and Janardhan[7], and Gowda and Jayarama[8] have reported mononuclear copper(II) and zinc(II) complexes of NPTZs. Kroener et al.[9] have studied the X-ray crystal structures of some cis- and trans-bis(2,2'-bipyridine) -bis(phenothiazine-S)ruthenium(II) hexaflurophosphates. Made Gowda et al. have previously studied the synthesis and characterization of some coordination compounds of NPTZs with rhodium(II/III), rhenium(VII), iridium(III/IV), molybdenum(IV/V), zinc(II), palladium(II) and mercury(II)[10 -16]. Chaitanya Lakshmi et al have reported transition metal-pyridoxine complexes[17-19]. We here report the synthesis and characterization of four transition metal complexes with $\mathrm{CP} . \mathrm{HCl}$ as the main ligand.

\section{Experimental}

\subsection{Materials}

Metal salts, zinc bromide, cadmium bromide, cadmium iodide and mercuric bromide, and the ligand, chlorpromazine hydrochloride (CP·HCl; 99\% pure) (Aldrich/Sigma Chemical Company) were used as supplied.

All solvents such as methanol, ethanol, diethyl ether, dimethyl sulfoxide, dimethyl formamide and DMSO- $\mathrm{d}_{6}$ (Cambridge isotope laboratories Inc.) were of ACS reagent grade and were used without further purification. Double 
distilled water was used in all preparations.

\subsection{Physical Measurements}

Elemental analyses of complexes were performed by Mi croanalysis Laboratory, University of Illinois, Ur bana-C hampaign, IL. Molar conductance was determined with the Conductance-Resistance meter. UV-Visible spectra were recorded on a Shimadzu UV1601 spectrophotometer. The infrared spectra were recorded on a Shimadzu FTIR 8400 spectrometer using potassium bromide pellets. ${ }^{1} \mathrm{H}-\mathrm{NMR}$ spectra were recorded on a JEOL-300MHz FT-NMR spectrometer in DMSO- $\mathrm{d}_{6}$. Mass magnetic susceptibilities of the complexes were measured at room temperature with a Johnson Matthey magnetic susceptibility balance which uses $\mathrm{HgCo}(\mathrm{SCN})_{4}$ as a calibrant.

\subsection{General Synthesis of Complexes}

A solution of the transition metal salt (x mmol) $\left(\mathrm{ZnBr}_{2}\right.$, $\mathrm{CdBr}_{2}, \mathrm{CdI}_{2}$ and $\mathrm{HgBr}_{2}$ ) dissolved in a minimum volume of $\mathrm{MeOH}$ was slowly added with stirring to a concentrated methanolic solution of $\mathrm{CP} . \mathrm{HCl}(2 \mathrm{x} \mathrm{mmol})$ and refluxed overnight. Each reaction mixture was cooled overnight at $0^{\circ} \mathrm{C}$ and the precipitated product isolated by suction filtration through a medium-glass fritted funnel. The product was washed with small amounts of cold water first followed by methanol, air-dried, and dried in vacuo over anhydrous $\mathrm{CaSO}_{4}$ in a desiccator. Each crude product was recrystallized twice from a hot saturated solution of the crude sample in methanol. The yield was determined.

\section{Results and Discussion}

The elemental analysis data listed in Table 1 show that the theoretical values are in agreement with the experimental ones. Physical properties of the new metal-CP.HCl complexes are presented in Table 2. Complexes are colored, microcrystalline, and relatively stable at room temperature with percent yields ranging from 71 to 93 . The complexes are slightly soluble in common polar solvents such as $\mathrm{MeOH}$ and readily soluble in DMF and DMSO. All complexes except $\mathrm{Zn}(\mathrm{II})$ complex are insoluble in water.

The stoichiometric reactions involved in the complex formation are represented by the equations (1) and (2) below.

$$
\mathrm{MX}_{2}+2 \mathrm{CP} . \mathrm{HCl} \stackrel{\mathrm{MeOH} / \mathrm{H}_{2} \mathrm{O}}{\longrightarrow} \mathrm{MX}_{2}(\mathrm{CP} . \mathrm{HCl})_{2}
$$

where $\mathrm{M}=\mathrm{Zn}$ (II) or $\mathrm{Cd}(\mathrm{II})$ and $\mathrm{X}$ is $\mathrm{Br}$ or I

$2 \mathrm{HgBr}_{2}+2 \mathrm{CP} . \mathrm{HCl} \stackrel{\mathrm{MeOH} / \mathrm{H}_{2} \mathrm{O}}{\longrightarrow} \mathrm{HgBr}_{2}(\mathrm{CP} . \mathrm{HBr})_{2}+\mathrm{HgCl}_{2}(2)$

In the reaction for the formation of $\mathrm{Hg}(\mathrm{II})$ complex (eq. (2)), the larger $\mathrm{Hg}(\mathrm{II})$ ion as a soft acid tends to preferentially coordinate with the soft base $\mathrm{Br}^{-}$as compared to the relatively harder $\mathrm{Cl}^{-}$ion of the ligand. The molecular formulations and structures of the complexes were determined on the basis of elemental analysis, molar conductance, UV-Vis, IR, and NMR data.

Table 1. Elemental data of the metal-CP.HCl complexes

\begin{tabular}{|c|c|c|c|c|}
\hline Complex, molecular formula & Ionic formula* (mol. Wt, $\mathrm{g} / \mathrm{mol})$ & $\% \mathrm{C} \exp$ (Theor) & $\% \mathrm{H} \exp$ (Thoer) & $\% \mathrm{~N} \exp ($ Theor) \\
\hline $\mathrm{ZnBr}_{2}(\mathrm{CP} . \mathrm{HCl})_{2}$ & $\begin{array}{c}{\left[\mathrm{ZnBr}\left(\mathrm{C}_{17} \mathrm{H}_{19} \mathrm{ClN}_{2} \mathrm{~S} . \mathrm{HCl}\right)_{2}\right] \mathrm{Br}} \\
(935.86)\end{array}$ & $\begin{array}{r}43.09 \\
(43.6) \\
\end{array}$ & $\begin{array}{r}4.42 \\
(4.3) \\
\end{array}$ & $\begin{array}{r}5.89 \\
(5.98) \\
\end{array}$ \\
\hline $\mathrm{CdBr}_{2}(\mathrm{CP} \cdot \mathrm{HCl})_{2} \cdot \mathrm{H}_{2} \mathrm{O}$ & $\begin{array}{c}{\left[\mathrm{CdBr}\left(\mathrm{C}_{17} \mathrm{H}_{19} \mathrm{ClN}_{2} \mathrm{~S} . \mathrm{HCl}\right)_{2}\right] \mathrm{Br} \cdot \mathrm{H}_{2} \mathrm{O}} \\
(1000.89)\end{array}$ & $\begin{array}{c}40.55 \\
(40.79) \\
\end{array}$ & $\begin{array}{r}3.84 \\
(4.22) \\
\end{array}$ & $\begin{array}{r}5.50 \\
(5.59) \\
\end{array}$ \\
\hline $\mathrm{CdI}_{2}(\mathrm{CP} \cdot \mathrm{HCl})_{2}$ & $\begin{array}{c}{\left[\mathrm{Cd}\left(\mathrm{C}_{17} \mathrm{H}_{19} \mathrm{ClN}_{2} \mathrm{~S} . \mathrm{HCl}\right)_{2}\right] \mathrm{I}_{2}} \\
(1076.88)\end{array}$ & $\begin{array}{l}37.46 \\
(37.9)\end{array}$ & $\begin{array}{c}3.49 \\
(3.74)\end{array}$ & $\begin{array}{l}5.02 \\
(5.2)\end{array}$ \\
\hline $\mathrm{HgBr}_{2}(\mathrm{CP} \cdot \mathrm{HBr})_{2} \cdot 2 \mathrm{H}_{2} \mathrm{O}$ & $\begin{array}{c}{\left[\mathrm{HgBr}\left(\mathrm{C}_{17} \mathrm{H}_{19} \mathrm{ClN}_{2} \mathrm{~S} . \mathrm{HBr}\right)_{2}\right] \mathrm{Br} .2 \mathrm{H}_{2} \mathrm{O}} \\
(1071.07)\end{array}$ & $\begin{array}{c}34.11 \\
(34.14)\end{array}$ & $\begin{array}{l}3.28 \\
(3.7)\end{array}$ & $\begin{array}{c}4.6 \\
(4.68)\end{array}$ \\
\hline
\end{tabular}

*Based on conductances shown in Table 2 .

Table 2. Physical properties of the metal-CP·HCl complexes

\begin{tabular}{|c|c|c|c|c|c|}
\hline Complex & $\begin{array}{c}\text { Melting point } \\
\left({ }^{\circ} \mathrm{C}\right)\end{array}$ & $\begin{array}{c}\text { Molar conductance (mho } \mathrm{cm}^{2} \\
\left.\mathrm{~mol}^{-1}\right)^{*}(\text { Ionic ratio })\end{array}$ & $\begin{array}{c}\text { Mass magnetic susceptibility }\left(10^{-6}\right. \\
\text { cgs })\end{array}$ & Color & Yield (\%) \\
\hline $\mathrm{ZnBr}_{2}(\mathrm{CP} . \mathrm{HCl})_{2}$ & $55-63$ & $\begin{array}{c}103.6 \\
(1: 1 \text { electrolyte })\end{array}$ & 4.15 & Lt. purple \\
\hline $\mathrm{CdBr}_{2}(\mathrm{CP} . \mathrm{HCl})_{2} \cdot \mathrm{H}_{2} \mathrm{O}$ & $50-59$ & $\begin{array}{c}103.6 \\
(1: 1 \text { electrolyte })\end{array}$ & 5.89 & Lt. purple \\
\hline $\mathrm{CdI}_{2}(\mathrm{CP} . \mathrm{HCl})_{2}$ & $60-70$ & $\begin{array}{c}124.3 * 217.6 * * \\
(1: 2 \text { electrolyte })\end{array}$ & 1.39 & Lt. yellow \\
\hline $\mathrm{HgBr}_{2}(\mathrm{CP} . \mathrm{HBr})_{2} .2 \mathrm{H}_{2} \mathrm{O}$ & $52-60$ & $\begin{array}{c}82.88 \\
(1: 1 \text { electrolyte })\end{array}$ & 52.6 \\
\hline
\end{tabular}

* $1.00 \mathrm{mM}$ complex solution in DMF and ** acetonitrile 
The molar conductances for the complexes, measured in DMF and acetonitrile solutions, presented in Table 2 indicate that all complexes behave as $1: 1$ electrolytes (except $\mathrm{CdI}_{2}$ complex which has 1:2 ionic ratio). Magnetic data of the complexes differ from the normal behavior of the $\mathrm{d}^{10}$ metal ions, $\mathrm{Zn}(\mathrm{II}), \mathrm{Cd}(\mathrm{II})$ and $\mathrm{Hg}(\mathrm{II})$, which are probably due to impurities[20]. The molecular formulations listed in Table 1 show that each complex contains a metal center and two chlorpromazine hydrochloride molecules as principal ligands. The other ligands include bromide and iodide ions. Additionally, complexes of $\mathrm{CdBr}_{2}$ and $\mathrm{HgBr}_{2}$ contain one and two $\mathrm{H}_{2} \mathrm{O}$ molecules, respectively, as water of hydration.

The UV-Visible spectral data of the ligand $(\mathrm{CP} . \mathrm{HCl})$ and its complexes are presented in Table 3. The maximum absorption band at $254.50 \mathrm{~nm}$ for $\mathrm{CP} . \mathrm{HCl}$ with a high molar absorptivity $\left(\varepsilon=1.69 \times 10^{4} \mathrm{M}^{-1} \mathrm{~cm}^{-1}\right)$ suggesting a $\pi \rightarrow \pi^{*}$ transition is shifted for the metal-CP.HCl complexes to a lower wavelength with high varying molar absorptivities ( $\varepsilon$ $\left.=(0.595-4.07) 10^{4} \mathrm{M}^{-1} \mathrm{~cm}^{-1}\right)$ indicating intraligand transitions of the $\pi \rightarrow \pi^{*}$ type that undergo hypsochromic shifts, confirming the metal-CP complexation[15-23].

Relevant IR absorption frequencies of the CP.HCl ligand and its metal complexes are presented in Table 4 . In the uncomplexed $\mathrm{CPHCl}$, the presence of a broad band in the $2000-2730 \mathrm{~cm}^{-1}$ range is assigned to the interaction of the quaternary ammonium ion, $\left(\mathrm{R}_{3} \mathrm{NH}\right)^{+}$ion with a halide ion[12-15,21,22]. In the IR spectra of the metal-CP.HCl complexes, this band has shifted with diminished intensity suggesting that the exocyclic $\mathrm{N}$ atom of the alkylamino group is indirectly involved in coordination with the metal center. A band observed in the $3000-2800 \mathrm{~cm}^{-1}$ region in the spectrum of $\mathrm{CP} . \mathrm{HCl}$ may be assigned to the heterocyclic nitrogen atom carrying an alkyl amine side chain[21,22]. This band of $\mathrm{CP} . \mathrm{HCl}$ shows a shift upon complexation suggesting its coordination to the metal(II) center[10-14]. In addition, $\mathrm{CdBr}_{2}$ and $\mathrm{HgBr}_{2}$ complexes show a broad band in the $3250-3560 \mathrm{~cm}^{-1}$ region, supporting the hydrogen bonded $\mathrm{OH}$ interactions of the water of hydration. The $\mathrm{Hg}(\mathrm{II}) \mathrm{com}-$ plex spectrum shows that bands in the $600-700 \mathrm{~cm}^{-1}$ and $715-740 \mathrm{~cm}^{-1}$ regions, attributable to the heterocyclic C-S-C modes, undergo a shift, suggesting heterocyclic sulfur atom as a coordination site[12,15,22]. The ${ }^{1} \mathrm{H}$ NMR data for the ligand, $\mathrm{CP} . \mathrm{HCl}$, and its complexes are presented in Table 5. Comparing the absorption peaks/multiplets and the chemical shifts of the uncomplexed ligand with those of corresponding complexes, it could be inferred that some of the resonance signals experience shifts upon complexation. Especially, in the free CP.HCl ligand, the broad singlet which occurs far down field $(\delta 10.80)$, attributable to the exocyclic $\left(\mathrm{R}_{3} \mathrm{NH}\right)^{+}$ proton, has shifted upfield on complexation indicating a change in this proton environment. This indirectly supports the existence of intramolecular hydrogen bonding between $\left(\mathrm{R}_{3} \mathrm{NH}\right)^{+}$and $\mathrm{X}^{-}$of the $\mathrm{MX}_{3}$ moiety[12,15,24].

Table 3. UV-Visible spectral data of the metal-CP·HCl complexes

\begin{tabular}{|c|c|c|c|}
\hline Complex/Ligand & $\lambda_{\max }(\mathrm{nm})$ & Molar absorptivity $\left(10^{4}, \mathrm{M}^{-1} \mathrm{~cm}^{-1}\right)$ & Transition \\
\hline $\mathrm{CP} . \mathrm{HCl}$ & 254.50 & 1.69 & $\pi \rightarrow \pi^{*}$ \\
\hline $\mathrm{ZnBr}_{2}(\mathrm{CP} . \mathrm{HCl})_{2}$ & 252.50 & 1.25 & $\pi \rightarrow \pi^{*}$ \\
\hline $\mathrm{CdBr}_{2}(\mathrm{CP} . \mathrm{HCl})_{2} \cdot \mathrm{H}_{2} \mathrm{O}$ & 239.50 & 4.07 & $\pi \rightarrow \pi^{*}$ \\
\hline $\mathrm{CdI}_{2}(\mathrm{CP} . \mathrm{HCl})_{2}$ & 255.50 & 1.12 & $\pi \rightarrow \pi^{*}$ \\
\hline $\mathrm{HgBr}_{2}(\mathrm{CP} . \mathrm{HBr})_{2} .2 \mathrm{H}_{2} \mathrm{O}$ & 237.50 & 0.595 & $\pi \rightarrow \pi^{*}$ \\
\hline
\end{tabular}

Table 4. Important IR absorptions of $\mathrm{CP} . \mathrm{HCl}$ and its metal complexes

\begin{tabular}{|c|c|c|c|c|}
\hline Complex/ Ligand & $\begin{array}{c}\text { Absorption of }\left(\mathrm{R}_{3} \mathrm{NH}^{+}\right) \\
\left(\mathrm{cm}^{-1}\right)\end{array}$ & $\begin{array}{c}\text { Absorption of }\left(>\mathrm{N}-\mathrm{R}^{1}\right) \\
\left(\mathrm{cm}^{-1}\right)\end{array}$ & $\begin{array}{c}\text { Absorption of }(\mathrm{C}-\mathrm{S}-\mathrm{C}) \\
\left(\mathrm{cm}^{-1}\right)\end{array}$ & $\begin{array}{c}\text { Absorption of }(\mathrm{OH}) \\
\left(\mathrm{cm}^{-1}\right)\end{array}$ \\
\hline $\mathrm{CP} . \mathrm{HCl}$ & $2730-2000$ & $3000-2800$ & 750 & - \\
\hline $\mathrm{ZnBr}_{2}(\mathrm{CP} . \mathrm{HCl})_{2}$ & $2900-2750$ & $3100-2930$ & 754 & - \\
\hline $\mathrm{CdBr}_{2}(\mathrm{CP} . \mathrm{HCl})_{2} \cdot \mathrm{H}_{2} \mathrm{O}$ & $2820-2600$ & $3200-2860$ & 754 & $3550-3250$ \\
\hline $\mathrm{CdI}_{2}(\mathrm{CP} \cdot \mathrm{HCl})_{2}$ & $2810-2640$ & $3200-2900$ & 752 & - \\
\hline $\mathrm{HgBr}_{2}(\mathrm{CP} \cdot \mathrm{HBr})_{2} \cdot 2 \mathrm{H}_{2} \mathrm{O}$ & $2820-2675$ & $3200-2940$ & 752 & $3600-3230$ \\
\hline
\end{tabular}

Table 5. ${ }^{1} \mathrm{H}-\mathrm{NMR}$ data of $\mathrm{CP} . \mathrm{HCl}$ and its metal complexes*

\begin{tabular}{|c|c|}
\hline Ligand/Complex & Chemical shift (multiplicity, protons) \\
\hline CP.HCl & $2.08(\mathrm{~m}, 2 \mathrm{H}), 2.68(\mathrm{~s}, 6 \mathrm{H}), 3.13(\mathrm{t}, 2 \mathrm{H}), 4.00(\mathrm{t}, 2 \mathrm{H}), 6.95-730(\mathrm{~m}, 7 \mathrm{H}), 10.80$ (br.s, $1 \mathrm{H})$. \\
\hline $\mathrm{ZnBr}_{2}(\mathrm{CP} . \mathrm{HCl})_{2}$ & $\begin{array}{c}2.00-2.05(\mathrm{~m}, 2 \mathrm{H}), 2.73(\mathrm{~s}, 6 \mathrm{H}) 3.11-3.16(\mathrm{t}, 2 \mathrm{H}), 3.94-3.99 \\
(\mathrm{t}, 2 \mathrm{H}), 7.13-7.22(\mathrm{~m}, 7 \mathrm{H}), 9.35(\mathrm{br} . \mathrm{s}, 1 \mathrm{H})\end{array}$ \\
\hline $\mathrm{CdBr}_{2}(\mathrm{CP} \cdot \mathrm{HCl})_{2} \cdot \mathrm{H}_{2} \mathrm{O}$ & 2.00-2.05(m,2H), $2.74(\mathrm{~s}, 6 \mathrm{H}), 3.11-3.16(\mathrm{t}, 2 \mathrm{H}), 3.994-3.997(\mathrm{t}, 2 \mathrm{H}), 7.01-7.22(\mathrm{~m}, 7 \mathrm{H}), 9.37(\mathrm{br} . \mathrm{s}, 1 \mathrm{H})$ \\
\hline $\mathrm{CdI}_{2}(\mathrm{CP} \cdot \mathrm{HCl})_{2}$ & 1.99-2.04 (m,2H), $2.74(\mathrm{~s}, 6 \mathrm{H}), 3.11-3.16(\mathrm{t}, 2 \mathrm{H}), 3.94-3.99(\mathrm{t}, 2 \mathrm{H}), 7.13-7.22(\mathrm{~m}, 7 \mathrm{H}), 9.25(\mathrm{br} . \mathrm{s}, 1 \mathrm{H})$ \\
\hline $\mathrm{HgBr}_{2}(\mathrm{CP} \cdot \mathrm{HBr})_{2} \cdot 2 \mathrm{H}_{2} \mathrm{O}$ & 2.02-2.08 (m,2H), $2.79(\mathrm{~s}, 6 \mathrm{H}), 3.11-3.16(\mathrm{t}, 2 \mathrm{H}), 3.94-3.99(\mathrm{t}, 2 \mathrm{H}), 7.02-7.22(\mathrm{~m}, 7 \mathrm{H}), 9.32(\mathrm{br} . \mathrm{s}, 1 \mathrm{H})$. \\
\hline
\end{tabular}

* In DMSO-d 6 
Crystals of sufficient quality required to permit $\mathrm{x}$-ray crystallographic analysis of the complexes could not be grown. Based on the discussed analytical data, tentative square pyramidal structures have been proposed for the complexes (Fig. 2.a-2.c). Similar structures have been reported for other phenothiazine-transition metal complexes[12-15,24]. A square pyramidal geometry around each $\mathrm{M}(\mathrm{II})$ metal center ( $\mathrm{sp}^{3} \mathrm{~d}$ hybridized), due to the steric constraints of the bidentate ligand not favoring a trigonal bipyramidal arrangement, involves two CP.HCl ligands and a monodentate bromide ion. With the relatively hard acids, $\mathrm{Zn}(\mathrm{II})$ and $\mathrm{Cd}(\mathrm{II})$ (Fig. 2.a), the CP.HCl binds through its heterocyclic $\mathrm{N}$ atom (as a hard base) directly and through the exocyclic $\mathrm{N}$ atom indirectly through the $\mathrm{H}$-bonding with a halide ion. The scorpion tail like $\mathrm{N}$-alkylamino group with its flexible bending mode is well suited for this kind of intramolecular H-bonding in NPTZs. The two protonated $\left(\mathrm{CPH}^{+}\right)$ligands coordinate to the $\mathrm{MX}_{3}$ unit of the compound through two $\mathrm{N}$ atoms resulting in a square planar $\mathrm{MX}_{2} \mathrm{~N}_{2}$ unit, which along with an axial $\mathrm{M}-\mathrm{X}$ bond represents a square-pyramidal geometry for each complex. In the $\left[\mathrm{HgBr}\left(\mathrm{C}_{17} \mathrm{H}_{19} \mathrm{ClN}_{2} \mathrm{~S} . \mathrm{HBr}\right)_{2}\right] \mathrm{Br} .2 \mathrm{H}_{2} \mathrm{O}$ complex (Fig. 2.b), the relatively soft acid, $\mathrm{Hg}(\mathrm{II})$ binds to the $\mathrm{CP}$ ligand through its heterocyclic $\mathrm{S}$ atom (as a soft base) directly and through the exocyclic $\mathrm{N}$ atom indirectly through its $\mathrm{H}$-bonding with a halide ion. In the $\left[\mathrm{Cd}\left(\mathrm{C}_{17} \mathrm{H}_{19} \mathrm{ClN}_{2} \mathrm{~S} . \mathrm{HCl}\right)_{2}\right] \mathrm{I}_{2}$ complex (Fig. 2.c), the $\mathrm{Cd}(\mathrm{II})$ center with an $\mathrm{sp}^{3}$ hybridization has a tetrahedral environment around it[14,15]. Similar transition metal complex structures have been reported in the literature[10-15].

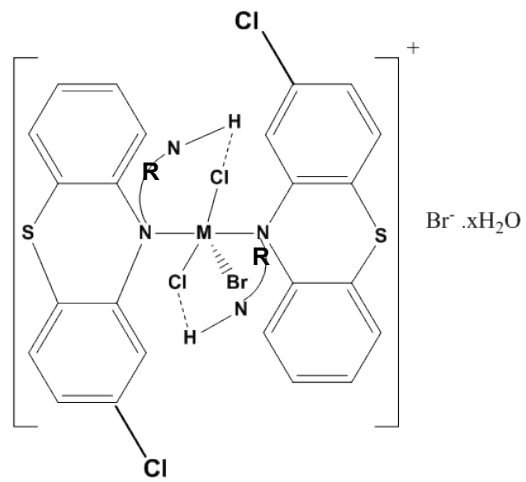

Figure 2a. Proposed square pyramidal structure for the complex ion, $\left[\mathrm{MBr}(\mathrm{CP} . \mathrm{HCl})_{2}\right]^{+}$, where $\mathrm{R}=-\mathrm{C}_{3} \mathrm{H}_{6}, \mathrm{M}=\mathrm{Zn}(\mathrm{II})$ or $\mathrm{Cd}(\mathrm{II})$ and $\mathrm{x}=0$ for $\mathrm{Zn}(\mathrm{II})$ and 1 for $\mathrm{Cd}(\mathrm{II})$

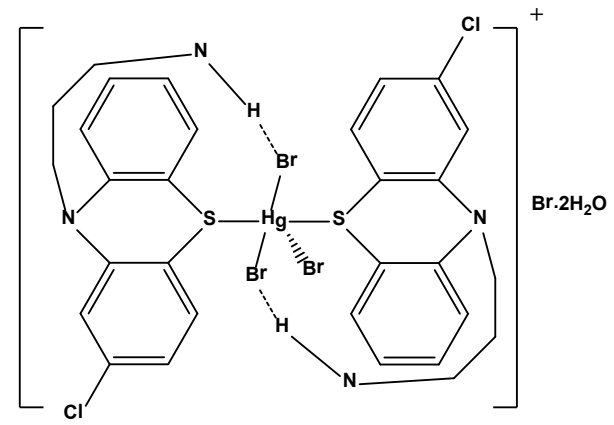

Figure 2b. Proposed square pyramidal structure for the complex ion, $\left[\mathrm{HgBr}(\mathrm{CP} . \mathrm{HBr})_{2}\right]^{+}$<smiles>[Z17]Cn1c2ccccc2sc2ccc(Cl)cc2n1C(Cl)(Cl)N1c2ccccc2Sc2ccc(Cl)cc21</smiles>

Figure 2c. Proposed tetrahedral structure for the complex ion, $\left[\mathrm{Cd}(\mathrm{CP} . \mathrm{HCl})_{2}\right]^{2+}$

\section{Conclusions}

Four transition metal-chlorpromazine complexes have been successfully prepared and characterized based on their spectroscopic data. Square-pyramidal and tetrahedral geometries have been proposed for the new complexes. The future work would be on the determination of antioxidant and free radical scavenging activities of these complexes using standard assays.

\section{ACKNOWLEDGEMENTS}

The authors are grateful to the Western Illinois University Research Council and the National Cancer Institute-NIH (AREA grant \# 1R15 CA115404-01) for support.

\section{REFERENCES}

[1] Snyder, S.H., 1976, Amer. J. Psychiatry, 133, 197.

[2] O. Bratfos and J.O. Haug, Acta Psychiat, Scand., 60, 1, 1979.

[3] A.R. Katritzky and A.J. Boulton (Eds.), Advances in heterocyclic Chemistry, Academic press, New York, 1968.

[4] Keshavan, B., and Seetharamappa, J., 1987, Polyhedron, 6(3), 465.

[5] Keshavan, B., and Seetharamappa, J., 1986, Synth. React. Met.-Org. Chem., 16(7), 979.

[6] Keshavan, B., and Janardhan, R., 1987, Ind. J. Chem., 26A, 975.

[7] Keshavan, B., and Janardhan, R., 1987, Ind. J. Chem., 25A, 1054.

[8] Sanke Gowda, H., and Jayarama., 1981, J. Inorg. Nucl. Chem., 43(10), 2329.

[9] Kroener, R., Heeg, M. J., and Deutsch, E., 1988, Inorg. Chem., 27,558 
[10] Made Gowda, N.M., and Phyu, H.P., 1992, Ttransition Met. Chem., 17, 467; H.P. Phyu, M.S. Thesis, Western Illinois University, Macomb, USA, May, 1991.

[11] Made Gowda, N.M., Phyu, H.P., and Ackerson, B.E., 1993, Transition Met. Chem., 18, 64.

[12] Made Gowda, N.M., Kyi, M.M., and Zhang, L., 1993, Transition Met.Chem., 18, 518; M.M. Kyi, MS. Thesis, Western Illinois University, Macomb, USA, December 1991; Made Gowda, N.M., and Zhang, L., 1994, Synth. React. Inorg. Met-Org. Chem., 24(5), 831; L. Zhang, M.S. Thesis, Western Illinois University, Macomb, USA, May, 1992.

[13] Made Gowda, N.M., Ackerson, B.E., Morland, M., and Rangappa, K.S., 1993, Transition Met. Chem., 18, 271.

[14] Made Gowda, N.M., Pacquette, H.L., Kim, D.H., and Jayaram, B., 1996, J. Mol. Struct., 382 ,129; Made Gowda, N.M., Vallabhaneni, R.K., Gajula, I., and AAFZAL, D., 1996, Synth. React Inorg. Met-Org. Chem, 26(4), 685.

[15] Made Gowda, N.M., Lawrence Pacquette, H., Kim Doo-Hyung, Jayaram, Beby, 1996, J. Mol. Struct, 382, 129-135; Made Gowda, N.M., Rouch, W.D., and Viet, A.Q., 1993, The Chemistry of copper and Zinc Triads., Royal Society of Chemistry, Cambridge, U.K, 117-120.

[16] Made Gowda, N.M., Vallabhaneni, R.K., Gajula, I., Ananda, S., 1997, J. Mol. Struct., 407, 125-130.

[17] Chaitanya Lakshmi G., Ananda S., and Made Gowda N.M., 2011, Synthesis, characterization, and antioxidant activity evaluation of pyridoxine and its transition metal complexes., Synthesis and Reactivity in Inorganic, Metal-Organic and Nano-Metal Chemistry, 41, 1-12.

[18] Chaitanya Lakshmi G., Ananda S., and Made Gowda N.M., 2009, Synthesis, Characterization and Antioxidant Activity of Zinc(II) and Ruthenium(III) Pyridoxine Complexes., Synthesis and Reactivity in Inorganic, Metal-Organic and Nano-Metal Chemistry, 39(8), 434-440.

[19] Chaitanya Lakshmi G., Ananda S., and Made Gowda N.M., 2010, Synthesis of Iron-Pyridoxine Complex by Solvothermal Process, Its Structural Characterization and Antioxidant Activity Evaluation., J. Chem. Chemical. Engg, 4(12), 33-37.

[20] J.M. Huheey, E.A. Keiter and R.L. Keiter, Inorganic Chemistry; Principles of Structures and Reactivity, $4^{\mathrm{th}}$ ed., Harper Collins College Publishers, 1993.

[21] L.J. Bellemy, The Infrared Spectra of Complex Molecules, Methuen, London, p.355, 1964.

[22] K. Nkamoto, Infrared Spectra of Inorganic and Coordination Compounds, Wiley Interscience, New York, 1970.

[23] D.A. Skoog and D.M. West, Principles of Instrumental Analysis, Saunders College, P.A, 1980, 171-173.

[24] Jayarama, Thimmaiah, K.N., and D'Souza, M.V., 1985, J. Indian Chem. Soc., 62, 418. 